
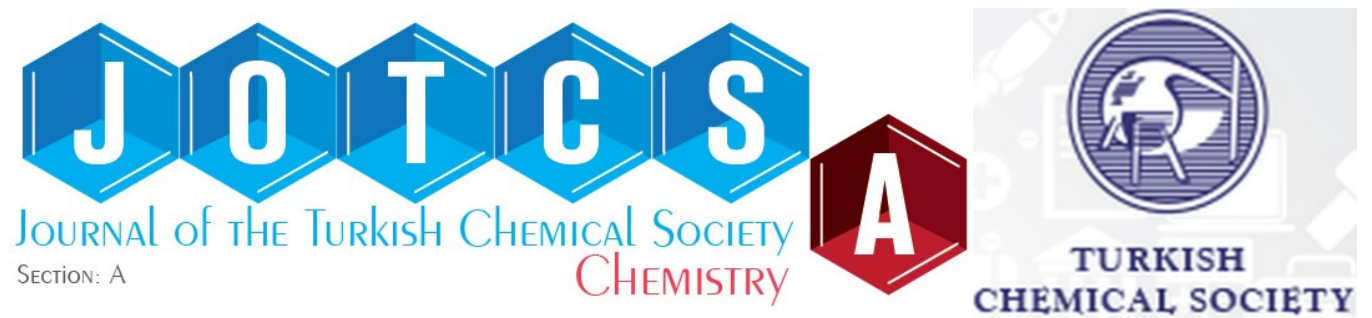

\title{
Synthesis and photophysical properties of a non-symmetrically substituted phthalocyanine-pyrene conjugate
}

\author{
Hande Pekbelgin Karaoğlu*, Ayfer Kalkan Burat \\ Istanbul Technical University, Department of Chemistry, TR34469, İstanbul, Turkey.
}

Abstract: An unsymmetrical zinc phthalocyanine ( $\mathrm{ZnPc})(\mathbf{5})$ bearing one pyrene (Py) and six tertbutylphenoxy units was synthesized in 3 steps. The unsymmetrical zinc phthalocyanine carrying the protecting group was synthesized in the first step. In the second stage, the protecting group was removed and in the final stage pyrene structure was introduced with the Sonagashira coupling reaction. The new compound was characterized by using spectroscopic techniques. The photophysical measurements of the conjugated structure were performed to determine the effect of the pyrene group on the fluorescence of Pc. It was determined that the absorption of the pyrene structure around $350 \mathrm{~nm}$ was overlapping with the B-band of phthalocyanine after conjugation. Fluorescence quantum yield $\left(\Phi_{F}\right)$ and lifetime $\left(T_{F}\right)$ were calculated. The fluorescence quenching examinations were performed by adding the different concentration of 1,4-benzoquinone (BQ) in $\mathrm{N}, \mathrm{N}$-dimethylformamide (DMF) and the Stern-Volmer constant $\left(\mathrm{K}_{\mathrm{sv}}\right)$ and quenching constant $\left(\mathrm{k}_{\mathrm{q}}\right)$ values of unsymmetrical zinc phthalocyanine (5) were determined.

Keywords: Zinc, pyrene, phthalocyanine, fluorescence, characterization.

Submitted: May 30, 2019. Accepted: July 16, 2019.

Cite this: Pekbelgin Karaoğlu $H$, Kalkan Burat A. Synthesis and photophysical properties of a nonsymmetrically substituted phthalocyanine-pyrene conjugate. JOTCSA. 2019;6(3):319-28.

DOI: https://doi.org/10.18596/jotcsa.572013.

*Corresponding author. E-mail: pekbelgin@itu.edu.tr.

\section{INTRODUCTION}

Phthalocyanines (Pcs) have 18 n-electron system and they are disc-like aromatic macrocycles. Due to the $\pi$-electron delocalization over the molecule, they have unique photophysical, photochemical, redox, and coordination properties, and high chemical and thermal stability (1). The properties of Pcs depend on both the electronic properties of the central metal cations and the nature of substituents. It is advantageous to substitute the functional groups at the peripheral or non-peripheral positions of the Pcs, since they provide solubility and it also tunes the color of the material. Substitution of functional groups also changes the electron density of the phthalocyanines and allows the use in various fields such as solar cells, sensors, liquid crystals, and nonlinear optics (2-6).

Although Pcs display good chemical and photochemical properties, their fluorescence properties are poor (7). Large central metals reduce the fluorescence by enhancement of the intersystem crossing to the triple state, hence restricting the applications of phthalocyanines in imaging (8). The fluorescence properties of the aromatic structure may alter by the interaction of a Pc core with a fluorescent probe like pyrene group. The chemical or physical binding of the fluorescent probe to the Pc causes a shift in the spectrum or a change in intensity (9).

It is well known that pyrene (Py) has a high quantum yield of fluorescence and a relatively long lifetime of singlet excited state (10). Pyrene is one of the most popular fluorescent chromophores used for photochemical applications. Pyrene derivatives with high quantum yields and lifetime, and are also valuable molecular probes for fluorescence spectroscopy (0.65 and $410 \mathrm{~ns}$, respectively, in ethanol at $293 \mathrm{~K}$ ) (11). In addition, pyrene and its derivatives have often been used as anchor groups to facilitate electron transfer into the acceptor domains (12). 
Phthalocyanine-pyrene (Pc-Py) conjugates appear to be promising candidates for solar cells, sensors, nonlinear optical and photovoltaic applications because of their photophysical and photochemical properties (13-16). According to the literature, the presence of pyrene groups in the structure of phthalocyanine improves the $\pi-\pi$ interaction between the Pc-Py and single-wall carbon nanotubes (SWCNT). Non-covalent functionalization of single-wall carbon nanotubes (SWNTs) with Pc-Py molecules were accomplished by Torres et al. to form stable hybrids (17). Durmus and coworkers synthesized hybrids of SWNT with phthalocyanines bearing one pyrene unit and studied their sensory response to ammonia vapor (18). They reported that the pyrene units and its derivatives display a strong affinity towards $\mathrm{sp}^{2}$-nanocarbon networks $(19,20)$. In another study, tri-and tetra-pyrene substituted indium phthalocyanines (InPcs) with strong triplet absorption and high triplet yields were investigated for the third- and second-order nonlinearities by Nykong et al. (15).

From the point of view, the aim of this study is to synthesize pyrenyl substituted unsymmetrical zinc phthalocyanine for the preparation of lightharvesting antennae. Although there are symmetrically or unsymmetrically substituted phthalocyanine-pyrene conjugated structures in the literature (21-24), unsymmetrically substituted zinc phthalocyanine in which the pyrenyl group was bound to the phthalocyanine ring, was synthesized for the first time. The photophysical properties of this new compound was investigated by fluorescence measurements.

\section{EXPERIMENTAL SECTION}

\section{Materials and methods}

All reported ${ }^{1} \mathrm{H}$ - NMR spectra were recorded on an Agilent VNMRS $500 \mathrm{MHz}$ spectrometer. Fluorescence and UV-Vis spectra were obtained using Perkin-Elmer LS55 fluorescence and Scinco LabProPlus UV/Vis spectrophotometers. FTIR spectra of the compounds were recorded on a Perkin-Elmer Spectrum One FTIR spectrometer. Mass spectra were measured on a Bruker Microflex LT MALDI-TOF MS spectrometer. The isotopic patterns for all assigned signals are in agreement with the calculated natural abundance. $\quad 4,5$-Bis-(4-tertbutylphenoxy)phthalonitrile (1), 4-(3-hydroxy-3methyl-1-butynyl)phthalonitrile

(2), 2,3,9,10,16,17-hexakis(tert-butylphenoxy)-23(3-hydroxy-3-methyl-1butynyl)phthalocyaninato zinc(II) (3) and 2,3,9,10,16,17-hexakis(tert-butylphenoxy)-23(ethynyl)phthalocyaninato zinc(II) (4) were prepared according to reported procedures (2527).

\section{Preparation}

Synthesis of 2,3,9,10,16,17-Hexakis(tertbutylphenoxy)-23-(pyrenyl)phthalocyaninato
zinc(II) (5): $100 \mathrm{mg}$ of compound 4 (0.07 mmol) was dissolved in $10 \mathrm{~mL}$ of dry tetrahydrofuran (THF) /trimethylamine (1:1) mixture and then 40 $\mathrm{mg}$ of 1-bromopyrene $(0.13 \mathrm{mmol}), 3 \mathrm{mg}$ of bis(triphenylphosphine)palladium(II) chloride $(0.004 \mathrm{mmol})$, and a catalytic amount of copper(I) iodide ( $1 \mathrm{mmol}, 0.1 \mathrm{mg}$ ) were added to this solution. The reaction mixture was heated to $60{ }^{\circ} \mathrm{C}$ for $24 \mathrm{~h}$ under nitrogen $\left(\mathrm{N}_{2}\right)$ atmosphere. Once the ethynyl derivative is consumed, monitored by TLC, the mixture was filtered over celite and the solvent was removed under vacuum. The green product was purified by column chromatography on silica gel using first hexane/dioxane (3:1) and then dichloromethane (DCM) /methanol (MeOH) $(50: 1)$ as eluents. Solubility: Soluble in THF, $\mathrm{CH}_{2} \mathrm{Cl}_{2}, \mathrm{DMF}$, and DMSO. Yield: $0.026 \mathrm{~g},(24 \%)$. FT-IR $\left(\mathrm{U}_{\max } / \mathrm{cm}^{-1}\right)$ : 3039 (Ar-C-H), 2957-2869 (Aliph. -C-H), 2206 $(\mathrm{C} \equiv \mathrm{C}), 1506$ (Ar-C=C), 1173 (Ar-O-Ar), 1087 (Ar-O-Ar). UV-Vis $\lambda_{\max }(\mathrm{nm})$ THF: 269, 356, 683; DMF: 267, 365, 684. ${ }^{1} \mathrm{H}-\mathrm{NMR}\left(500 \mathrm{MHz} \mathrm{CDCl}_{3}\right)$ : ठ, ppm 7.65-7.33 (42 H, m, Ar-H) $1.30(54 \mathrm{H}, \mathrm{s}$, $\mathrm{CH}_{3}$ ). Anal. Calc. for $\mathrm{C}_{110} \mathrm{H}_{96} \mathrm{~N}_{8} \mathrm{O}_{6} \mathrm{Zn}$ (1689.68 $\mathrm{g} / \mathrm{mol}) \%: \mathrm{C}, 78.11 ; \mathrm{H}, 5.72 ; \mathrm{N}, 6.63$ Found: C, 78.12; H, 5.69; N, 6.56. MS (MALDI-TOF): $\mathrm{m} / \mathrm{z}$ $1689.66[\mathrm{M}]^{+}$.

\section{Photophysical parameters}

Fluorescence quantum yields and lifetimes:

The comparative method was used to determine the fluorescence quantum yields $\left(\Phi_{F}\right)$ according to the Eq. (1) below $(28,29)$, utilizing nonsubstituted ZnPc in DMF as the standard $\left(\Phi_{\mathrm{F}}=\right.$ $0.17)(28,29)$ :

$$
\emptyset_{\mathrm{F}}=\emptyset_{\mathrm{F}}(\mathrm{Std}) \frac{\mathrm{FA} \mathrm{Atd}_{\mathrm{St}} \eta^{2}}{\mathrm{~F}_{\mathrm{Std}} A \eta_{\mathrm{Std}}^{2}}
$$

where $F$ and $F_{\text {Std }}$ are the areas under the fluorescence emission curves of the phthalocyanine (5) and the standard, respectively. Astd and $A$ are the respective absorbances at the excitation of standard and $\mathbf{5}$, $\eta_{\text {std }}$ and $\eta$ are the refractive index of solvent ( $\eta_{D M F}$ $=1.496$ ) used for the standard and sample.

The fluorescence lifetime $\left(T_{F}\right)$, which is the average time of the molecule at the excited state before fluorescing, was found using the PhotochemCAD program and the Strickler-Berg equation. The fluorescence quantum yield $\left(\Phi_{\mathrm{F}}\right)$ and the fluorescence lifetime $\left(T_{F}\right)$ value are directly proportional. The natural radiative lifetime $\left(T_{0}\right)$ was calculated with Eq. $(2)(28,29)$ :

$$
\emptyset_{\mathrm{F}}=\tau \mathrm{F} / \tau_{0}
$$

Fluorescence quenching by 1,4-benzoquinone: Fluorescence quenching experiments were carried out in DMF with the addition of $\mathrm{BQ}$ solutions ranging from 0 to $0.040 \mathrm{M}$ into the $\mathrm{ZnPC}$ solution. With the addition of $\mathrm{BQ}$, an energy 
transfer takes place between the excited $\mathrm{ZnPc}$ (fluorophore) and the $\mathrm{BQ}$ (quencher). The fluorescence spectra of $\mathrm{ZnPc}$ were recorded each time after the addition of different concentration of $B Q$. Changes in fluorescence intensity due to $\mathrm{BQ}$ concentration were consistent with the kinetic mechanism of the Stern-Volmer (SV) equation (Eq 3) (30):

$$
\frac{I_{0}}{I}=1+K_{S V}[B Q]
$$

where $I_{0}$ and I are the fluorescence intensities of fluorophore in the absence and presence of quencher, respectively. [BQ] is the concentration of the quencher and $\mathrm{K}_{S V}$ is the Stern-Volmer constant. $\mathrm{K}_{S V}$ is the product of the bimolecular quenching constant $\left(\mathrm{K}_{q}\right)$ and the $\mathrm{T}_{F}$, and is shown in Eq. (4) (31):

$$
K_{S V}=k_{q} \times \tau_{F}
$$

The ratios of $\mathrm{I}_{0} / \mathrm{I}$ were calculated and plotted against [BQ] according to Eq. (4), and $\mathrm{K}_{S V}$ is determined from the slope.

\section{RESULTS AND DISCUSSION}

Synthesis and spectroscopic
characterization

There are three methods for the preparation of usymmetrically substituted Pcs. These include a statistical condensation of two different phthalonitriles (32-34), a polymeric support method $(35,36)$ and a ring-expansion of subphthalocyanine (SubPc) (37, 38). Sub-Pcs undergo ring expansion when reacted with diaminoisoindoline or its analogues, resulting in the $A_{3} B$ type phthalocyanines. Although ring expansion reaction is highly selective and the $A_{3} B$ phthalocyanine is the major product, this only applies to limited phthalonitriles. It is because the ring expansion reaction is dependent on the experimental conditions and the electronic properties of the reactants (39-42). Despite the variety of commercially available polymeric supports, phthalonitriles having a functional group that can bind to the polymer and then be separated under acidic or alkaline conditions is limited. Therefore, the synthesis of $A_{3} B$ type phthalocyanines by the polymeric support route is restricted $(43,44)$. Since the starting materials used in this study do not have a functional group that can bind to the polymer, the statistical condensation method is preferred. If the reactivities of the two phthalonitrile involved in the condensation are similar, the symmetrical $A_{4}$ type Pc $(33 \%)$, the asymmetrical $A_{3} B$ type Pc $(44 \%)$ and the remaining $\operatorname{Pcs}(23 \%)$ can be obtained using a $3: 1(A: B)$ ratio. In this method, the use of phthalonitriles with different solubility properties will facilitate purification of the targeted asymmetric phthalocyanine.

Phthalonitrile $\mathbf{1}$ and phthalonitrile $\mathbf{2}$ were used as starting materials. Compound $\mathbf{1}$ was synthesized from the reaction of 4-tert-butylphenol with 4,5dichlorophthalonitrile in dimethyl sulfoxide (DMSO). The reaction was completed at $90^{\circ} \mathrm{C}$ for 4 hours and potassium carbonate $\left(\mathrm{K}_{2} \mathrm{CO}_{3}\right)$ was used as the base (25). Nitrile $\mathbf{2}$ was prepared by the reaction of 2-methylbut-3-yn-2-ol with 4iodophthalonitrile under typical Sonogashira reaction conditions (26, 45). The mixed condensation of phthalonitrile precursors $\mathbf{1}$ and $\mathbf{2}$ with zinc chloride $\left(\mathrm{ZnCl}_{2}\right)$ in 2dimethylaminoethanol (DMAE) at $145^{\circ} \mathrm{C}$ afforded the corresponding zinc phthalocyanine (3) (Scheme 1). The desired phthalocyanine (3) was purified by column chromatography. The dioxane:hexane $(1: 3)$ mixture was used as the eluent on silica gel and the compound was obtained in moderate yield (14\%) (27). The protecting group was then removed by treatment with sodium hydroxide in toluene to give the ethynyl derivative (4) (27). The resulting crude product was purified by column chromatography on silica gel by using dioxane:hexane (1:5) as eluent. Phthalocyanine 4 was obtained as green solid in a $69 \%$ yield. The Sonagashira coupling reaction between compound 4 and 1bromopyrene in THF/trimethylamine with bis(triphenylphosphine)palladium(II)chloride and copper(I)iodide as catalyst at $60{ }^{\circ} \mathrm{C}$ under $\mathrm{N}_{2}$ atmosphere led to the formation of $\mathbf{5}$ in $24 \%$ yield. 
<smiles>[R]c1cc(C#N)c([R])cc1C#N</smiles>

1<smiles>CC#CC</smiles>

2

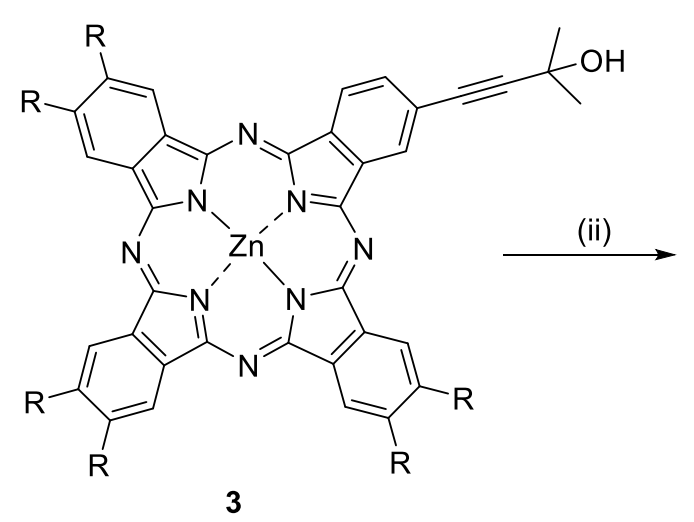

3

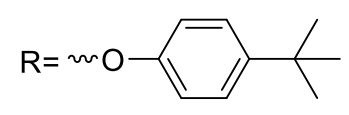

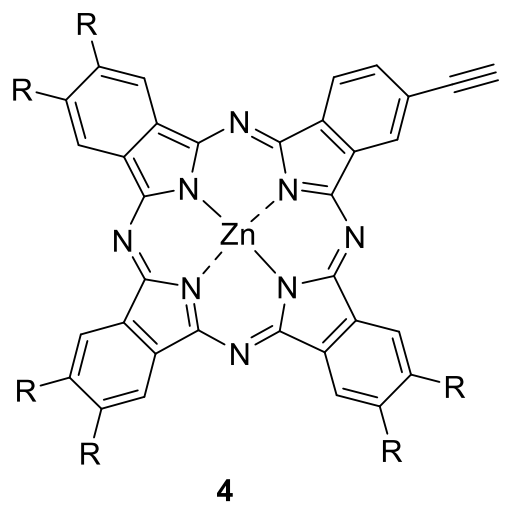

4

(iii)

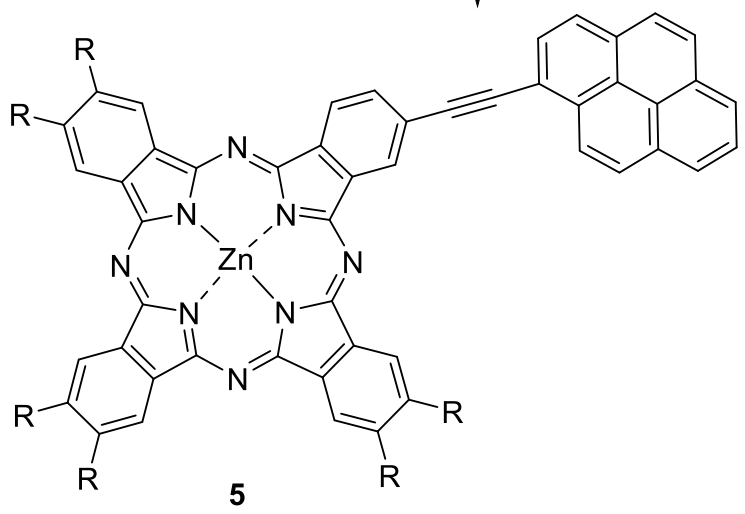

Scheme 1. Synthetic route to unsymmetrical $\mathrm{ZnPc}$ (5) (i) $\mathrm{ZnCl}_{2}, \mathrm{DMAE}, 24 \mathrm{~h}$, reflux. (ii) $\mathrm{NaOH}$, toluene, reflux, $6 \mathrm{~h}$. (iii) 1-Bromopyrene, $\mathrm{Pd}\left(\mathrm{PPh}_{3}\right)_{2} \mathrm{Cl}_{2}$, $\mathrm{CuI}, \mathrm{THF}$, Triethylamine, $60{ }^{\circ} \mathrm{C}$, $24 \mathrm{~h}$.

The spectroscopic characterization of the newly synthesized compound (5) included ${ }^{1} \mathrm{H} N M R$, IR, mass and UV-Vis. In the FT-IR spectrum of compound 5, aromatic $\mathrm{CH}$, aliphatic $\mathrm{CH}, \mathrm{C} \equiv \mathrm{C}$ and $\mathrm{C}-\mathrm{O}-\mathrm{C}$ vibrations were observed at 3039, 29572869, 2206 and $1266-1212 \mathrm{~cm}^{-1}$, respectively. In the ${ }^{1} \mathrm{H}$ NMR spectrum of $\mathbf{5}$, the aromatic protons were observed between $7.65-7.33 \mathrm{ppm}$ as multiplet in $\mathrm{CDCl}_{3}$. The aliphatic $\mathrm{CH}_{3}$ protons were resonated at $1.30 \mathrm{ppm}$ as singlet. In the mass spectrum of compound $\mathbf{5}$, the presence of the characteristic molecular ion peak at $\mathrm{m} / \mathrm{z}=$ $1689.66 \mathrm{H}^{+}$confirmed the proposed structure.

In the UV spectra of compounds ZnPc (4) and ZnPc-Py (5) in DMF, the $\mathrm{B}$ bands and $\mathrm{Q}$ bands were detected at 354 (4), 356 (5) and 678 (4), 683 (5) nm, respectively (Figure 1). Two absorption peaks were observed at 267 and 346 $\mathrm{nm}$ in the spectrum of pyrene in DMF (Figure $\mathbf{1}$ ). The $\mathrm{Q}$ band of $\mathrm{ZnPc}$ (5) slightly red shifted ( $5 \mathrm{~nm}$ ) after coordination with Py. The reason for this shift is the extended $\Pi$ conjugation of phthalocyanine structure (23). After the conjugation, the $\mathrm{B}$ band of $\mathrm{ZnPc}-\mathrm{Py}$ (5) was almost as intense as its $Q$ band because of the pyrene absorption in the $B$ band region $(21,22)$. As seen in the literature, the Soret band of phthalocyanine (5) overlaps with the absorption of pyrene unit at around $346 \mathrm{~nm}$ (21-23). 


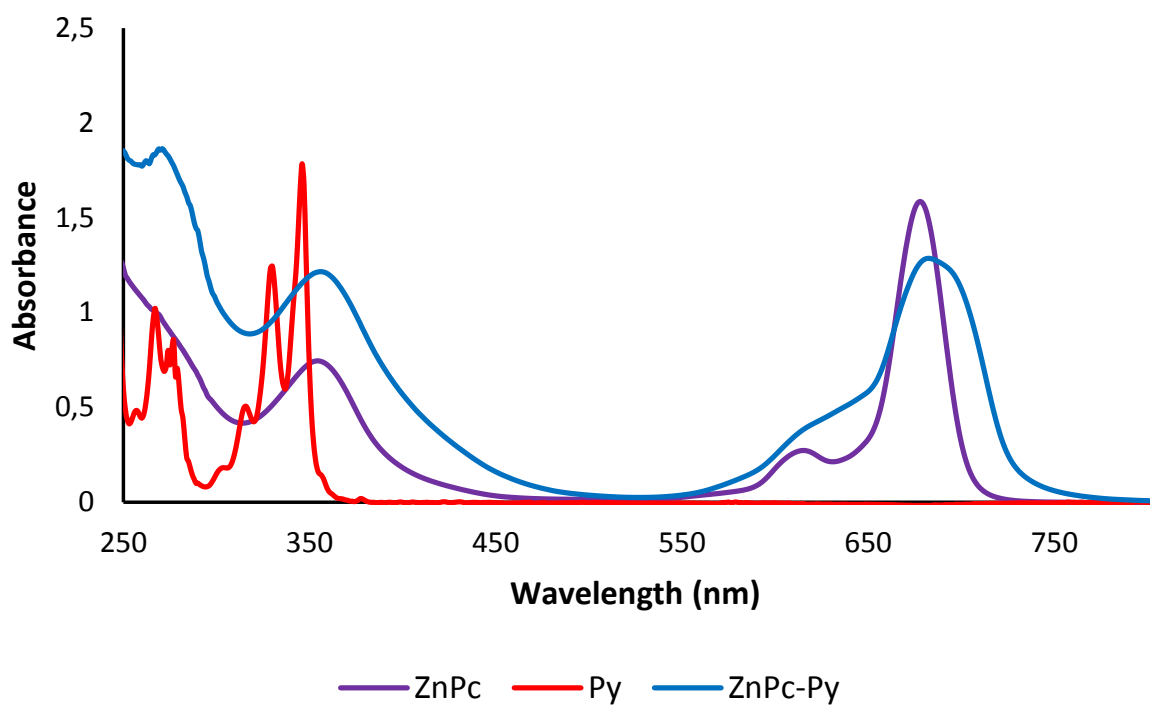

Figure 1. UV/Vis spectra of $\mathrm{ZnPc}(\mathbf{4}), \mathrm{ZnPc}-\mathrm{Py}(\mathbf{5})$ and pyrene (Py) in DMF $\left(6 \times 10^{-5} \mathrm{M}\right)$

The fluoresence measurements and fluorescence quenching studies of $\mathbf{5}$ were performed in DMF upon exitation at $615 \mathrm{~nm}$. The fluorescence emission, excitation, and absorption spectra of $\mathbf{5}$ were shown in Figure 2. Fluorescence emission peak of $\mathbf{5}$ was detected at $705 \mathrm{~nm}$ and Stokes' shifts was evaluated as $27 \mathrm{~nm}$. The observed Stokes' shift was within the region $\sim 20-30 \mathrm{~nm}$ as typical for Pc complexes (46). The excitation spectrum was similar to absorption spectrum and both were mirror images of the fluorescent spectra for $\mathbf{5}$ in DMF. This shows that the nuclear configurations of the ground and excited states are similar and not affected by excitation (28, 29).

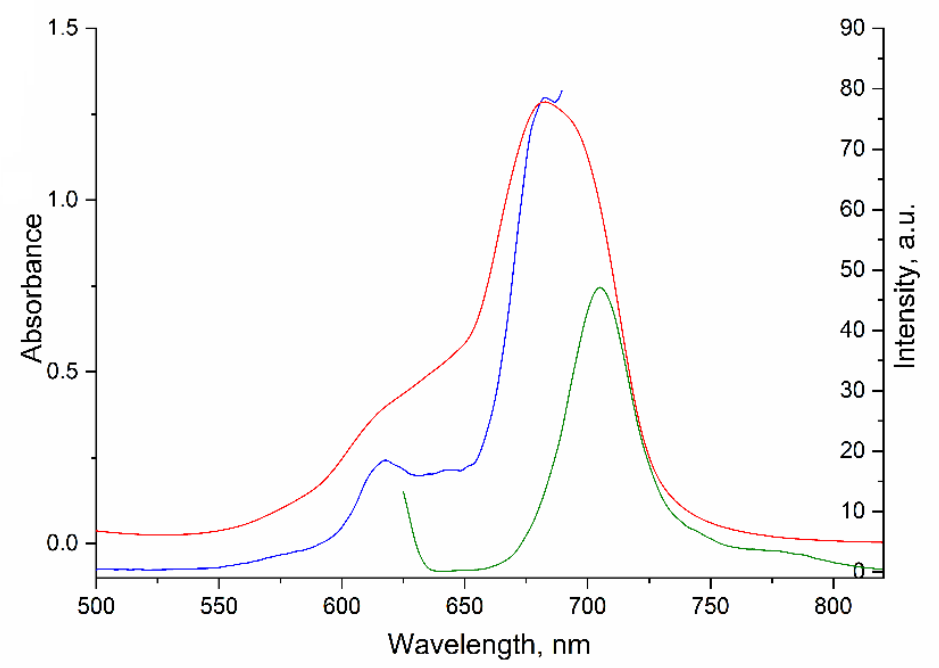

Figure 2. Absorption (red), excitation (blue) and emission (green) spectra of 5 in DMF $\left(4 \times 10^{-6} \mathrm{M}\right)$

The fluorescence quantum yield $\left(\Phi_{F}\right)$ of compound 5 was calculated as 0.173 which is very close to the $\Phi_{\mathrm{F}}$ value of the $\mathrm{ZnPc}$ used as reference. According to the literature, the insertion of a diamagnetic central metal is known to increase the fluorescence quantum yield $\left(\Phi_{F}\right)$ (47). For standard $\mathrm{ZnPc}$ the $\Phi_{\mathrm{F}}$ value is known to be 0.17 in DMF $(28,29)$.

According to the literature, Özçeşmeci and coworkers synthesized phthalocyanines bearing four pyrene units and studied their photophysical properties (21). In another study performed by Sürgün et al., pyrenyl substituted phthalocyanine synthesis and photophysical measurements were performed (22). In these studies where the pyrene groups were not conjugated to the phthalocyanine ring, the fluorescence quantum yields measured for ZnPc's were close to the value of the standard ZnPc. ZnPc-Py conjugate structure was accomplished by Ogbodu and coworkers (23). They reported that the fluorescence quantum yield of the pyrene substituted unsymmetrical ZnPc was close to the reference yield. In this study, we extend the conjugation of the Pc by adding a pyrenyl group and the fluorescence quantum yield of $\mathbf{5}$, was found to be very close to the value in the literature. 
The natural radiative lifetime $\left(T_{0}\right)$ value was calculated as $13.07 \mathrm{~ns}$ and the fluorescence lifetime $\left(k_{F}\right)$ value was 2.26 ns. For the unsubstituted $\mathrm{ZnPc}$, the $\mathrm{T}_{0}$ and $\mathrm{k}_{\mathrm{F}}$ values are 6.05 ns and 1.03 ns, respectively. It was observed that the natural radiative lifetime and the fluorescence lifetime values for $\mathbf{5}$ were higher than nonsubstituted ZnPc in DMF.

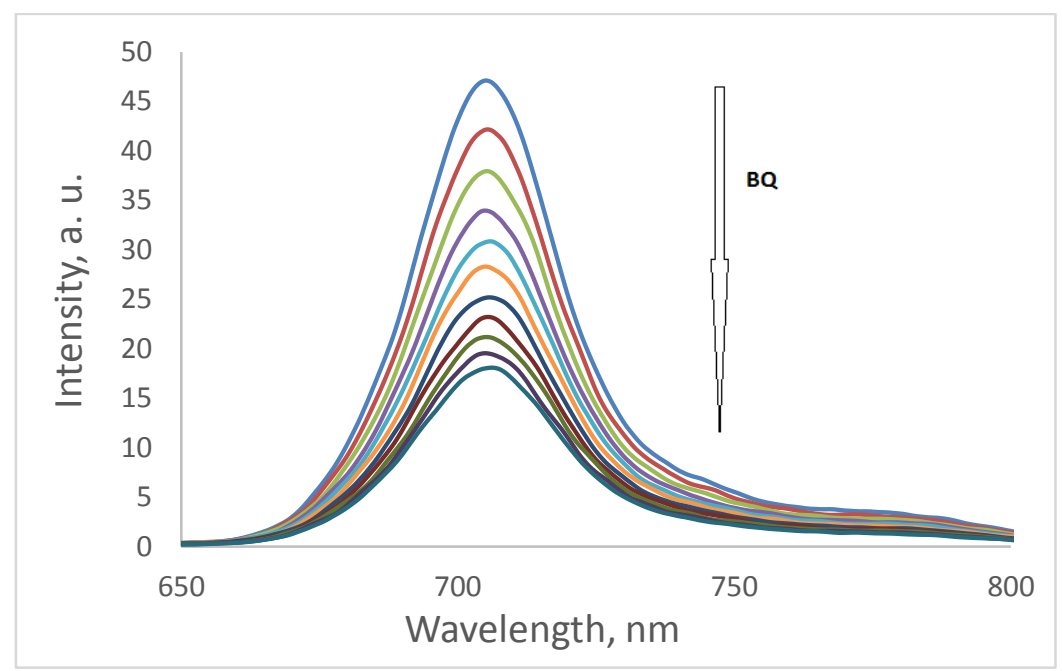

Figure 3. Fluorescent emission spectral changes of $5\left(4 \times 10^{-6} \mathrm{M}\right)$ in DMF in which different concentrations of hydroquinone in DMF were added as quencher. [BQ] $=0.000,0.008,0.016,0.024$, $0.032,0.040 \mathrm{M}$

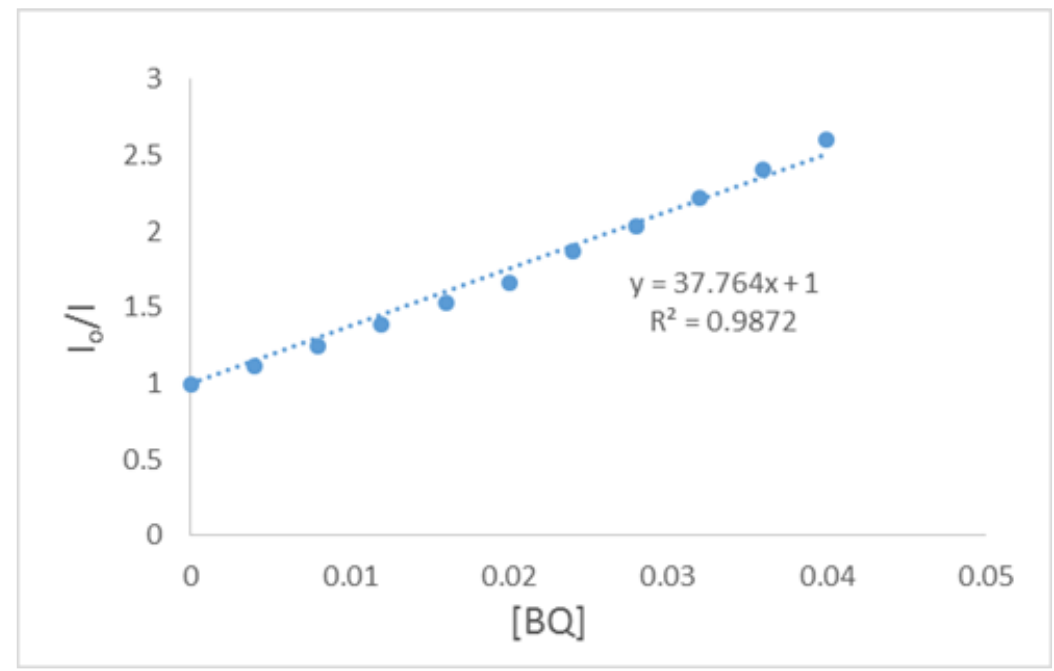

Figure 4. Stern-Volmer plot of $\mathbf{5}$ for $\mathrm{BQ}([\mathrm{BQ}]=0.000,0.008,0.016,0.024,0.032,0.040 \mathrm{M})$

The fluorescence quenching of the compound $\mathbf{5}$ by benzoquinone (BQ) in DMF was found to obey Stern-Volmer kinetics, which is consistent with diffusion-controlled bimolecular reactions. The emission spectrum of $\mathbf{5}$ with the addition of varying concentrations of $\mathrm{BQ}$ is shown in Figure 3. As the concentration of $\mathrm{BQ}$ increases, the intensity of $\mathbf{5}$ decreases in parallel to the increasing concentration of $\mathrm{BQ}$. The slope of the graph studied for equation 3 is linear, indicating that the diffusion controlled quenching mechanisms. The $\mathrm{K}_{S V}$ value from the slope of the graph was found to be $37.76 \mathrm{M}^{-1}$ (Figure 4) (28, 29). $k_{q}$ is the bimolecular quenching constant of $\mathbf{5}$ in DMF for BQ quenching and the value for $\mathbf{5}$ is $1.67 \times 10^{10} \mathrm{~s}^{-1}$. The $\mathrm{K}_{s v}$ and $\mathrm{k}_{q}$ values of compound 5 are smaller than unsubstituted $\mathrm{ZnPc}\left(\mathrm{K}_{s v}=\right.$ $57.60 \mathrm{M}^{-1}, \mathrm{k}_{q}=5.59 \times 10^{10} \mathrm{~s}^{-1}$ ).

\section{CONCLUSION}

In the present work, pyrene and tertbutylphenoxy substituted unsymmetrical zinc phthalocyanine was synthesized and characterized by various spectroscopic methods and confirmed the proposed structure. The overlap of the Soret band of Pc with the band at $346 \mathrm{~nm}$ of Py caused an increase in the intensity of $B$ band of compound $\mathbf{5}$ after conjugation. The slight red shifting of $Q$ band of Pc was also determined after Pc-Py conjugation. The photophysical properties of Pc-Py (5) conjugate was investigated and compared with an unsubstituted $\mathrm{ZnPc}$. The fluorescence quantum yield of compound $\mathbf{5}$ is close to unsubstituted $\mathrm{ZnPc}$, while its lifetime is higher than that of 
unsubstituted ZnPc. In addition, the fluorescence quantum yield of compound $\mathbf{5}$ was compared with the fluorescence quantum yield of other tetrasubstituted ZnPc substituted with pyrene groups in the literature (21-23). The fluorescence quantum yield of $\mathbf{5}$ is in agreement with the literature values. Furthermore, the fluorescence quenching studies were performed by benzoquinone typically. The Stern-Volmer kinetics were also investigated in DMF. In comparasion with unsubstituted zinc phthalocyanine, compound $\mathbf{5}$ showed lower $\mathrm{K}_{s v}$ and $\mathrm{k}_{q}$ values.

\section{ACKNOWLEDGEMENTS}

This work was supported by the Research Fund of the Istanbul Technical University.

\section{REFERENCES}

1. Schmid G, Sommerauer M, Geyer M, Hanack M, Leznoff CC. A.B.P. Lever (Eds.), Phthalocyanines: Properties and Applications, vol. 4, VCH Publishers, New York, 1996, pp. 1-18.

2. Basova TV., Parkhomenko RG, Polyakov M, Gürek AG, Atilla D, Yuksel $F$, et al. Effect of dispersion of gold nanoparticles on the properties and alignment of liquid crystalline copper phthalocyanine films. Dye Pigment. 2016; 125: 266-73.

3. Çimen $Y$, Ermiş $E$, Dumludağ $F$, Özkaya $A R$, Salih B, Bekaroğlu Ö. Synthesis, characterization, electrochemistry and VOC sensing properties of novel ball-type dinuclear metallophthalocyanines. Sensors Actuators, B Chem. 2014; 202: 113747.

4. Nagel S, Lener M, Keil C, Gerdes R,Lapok L, Gorun SM, Schlettwein D. Electrochromic Switching of Evaporated Thin Films of Bulky, Electronic Deficient Metallo-Phthalocyanines. J Phys Chem C. 2011; 115: 8759-8767.

5. Maya EM, Garcia-Frutos EM, Vazquez $P$, Torres T, Martin G, Rojo G, Agullo-Lopez F, GonzalezJonte RH, Ferro VR, Vega JMG, Ledoux I, Zyss J. Novel Push-Pull Phthalocyanines as Targets for Second-Order Nonlinear Applications. J Phys Chem A. 2003; 107: 2110-2117.

6. Walter MG, Rudine AB, Wamser CC. Porphyrins and phthalocyanines in solar photovoltaic cells. J Porphyrins Phthalocyanines. 2010; 14: 759-792.

7. Liu MO, Tai $\mathrm{CH}$, Teh Hu A. The fluorescent and photoelectric conversion properties of phthalocyanineeperylene tetracarboxylic complexes. J Photochem Photobiol A. 2004; 165: 193-200.

8. Nyokong $T$, Antunes $E$. in The Handbook of Porphyrin Science, ed. Kadish KM, Smith KM and
Guilard R. World Scientific. Singapore, 2010, ch. 34 , vol 7.

9. Frahn MS, Abellon RD, Jager WF, Luthjens LH, Warman JM. Synthesis and characterization of a new fluorogenic probe molecule $\mathrm{N}$-(1pyrene)methacrylamide for monitoring radiationinduced polymerization. Nucl Instrum Methods Phys Res. Sect B. 2001; 185: 241-47.

10. Lerner MG, Resczenski JM, Amin A, Johnson RR, Goldsmith JI, Johnson ATC. Toward quantifying the electrostatic transduction mechanism in carbon nanotube molecular sensors. J Am Chem Soc. 2012; 134: 14318.

11. Valeur B. Molecular fluorescence principles and applications. Germany, Weinheim: WileyVCH; 2002.

12. Karabacak $M$, Cinar $M$, Kurt $M$, Sundaraganesan N. Experimental and theoretical FTIR and FT-Raman spectroscopic analysis of 1pyrenecarboxylic acid. Spectrochim Acta Part A: Mol Biomol Spectrosc. 2013; 114: 509-519.

13. Roth A, Ragoussi ME, Wibmer L, Katsukis G, Torre G, Torres T, Guldi DM. Electron-accepting phthalocyanine-pyrene conjugates: towards liquid phase exfoliation of graphite and photoactive nanohybrid formation with graphene. Chem Sci. 2014; 5: 3432-3438.

14. Kaya EN, Tuncel S, Basova TV, Banimuslem $H$, Hassan A, Gürek AG, Ahsen V, Durmuş $M$. Effect of pyrene substitution on the formation and sensor propertiesof phthalocyanine-single walled carbon nanotube hybrids. Sensors and Actuators B. 2014 ; 199: 277-283.

15. Sanusi K, Nyokong T. Effects of pyrene on the photophysical and two-photon absorption-based nonlinear optical properties of indium(III) phthalocyanines. Journal of Coordination Chemistry. 2014; 67: 2911-2924.

16. Kumar RS, Son YA. Synthesis, photophysical and aggregation properties of novel phenanthrene and pyrene substituted phthalocyanines. Korean Chem Eng Res. 2018; 56(6): 792-797.

17. Bartelmess J, Ballesteros B, Torre G, Kiessling D, Campidelli S, Prato M, Torres T, Guldi DM. Phthalocyanine-pyrene conjugates: A powerful approach toward carbon nanotube solar cells. J Am Chem Soc. 2010; 132: 16202-16211.

18. Kaya EN, Basova TV, Polyakov M, Durmuş M, Kadem B, Hassan A. Hybrid materials of pyrene substituted phthalocyanines with single-walled carbon nanotubes: structure and sensing properties. RSC Adv. 2015; 5: 91855-91862. 
19. Su Q, Pang S, Alijani V, Li C, Feng X, Müllen $\mathrm{K}$. Composites of graphene with large aromatic molecules. Adv Mater. 2009; 21: 3191-3195.

20. Mann JA, Rodriguez-Lopez J, Abruna HD, Dichtel WR. Multivalent binding motifs for the noncovalent functionalization of graphene. J Am Chem Soc. 2011 ; 133: 17614-17617.

21. Özçeşmeci İ, Gelir A, Gül A. Synthesis and photophysical properties phthalocyanineepyrene dyads. Dye Pigment. 2012; 92: 954-960.

22. Sürgün $S$, Arslanoğlu $Y$, Hamuryudan E. Synthesis of non-peripherally and peripherally substituted zinc (II) phthalocyanines bearing pyrene groups via different routes and their photophysical properties. Dye Pigment. 2014; 100: $32-40$.

23. Ogbodu RO, Antunes E, Nyokong T. Physicochemical properties of a zinc phthalocyanine - pyrene conjugate adsorbed onto single walled carbon nanotubes. Dalton Trans. 2013; 42: 10769-10777.

24. Ke L, Min J, Adam M, Gasparini N, Hou Y, Perea JD, Chen W, Zhang $H$, Fladischer S, Sale, Erdmann Spiecker AC, Tykwinski RR, Brabec CJ, Ameri T. A series of pyrene-substituted silicon phthalocyanines as near-ir sensitizers in organic ternary solar cells. Adv Energy Mater. 2016; 6 (1502355): 1-13.

25. Maree SE, Nyokong T. Syntheses and photochemical properties of octasubstituted phthalocyaninato zinc complexes. J Porphyrins Phthalocyanines. 2001; 5: 782-792.

26. Maya EM, Vazquez P, Torres T. Homo- and hetero-dimetallic ethynyl- and butadiynylbridged bisphthalocyaninato complexes. Chem Commun. 1997; 1175-76.

27. Garcia-Iglesias M, Torres T, GonzalezRodriguez D. Well-defined, persistent, chiral phthalocyanine

nanoclusters via G-quadruplex assembly. Chem Commun. 2016; 52: 9446-9449.

28. Karaoğlu HRP, Yenilmez HY, Koçak MB. Phthalocyanines formed from several precursors: synthesis, characterization, and comparative fluorescence and quinone quenching. Journal of Coordination Chemistry. 2018; 71(15): 23402357.

29. Zorlu Y, Dumoulin F, Durmuş M, Ahsen V. Comparative studies of photophysical and photochemical properties of solketal substituted platinum (II) and zinc (II) phthalocyanine sets. Tetrahedron. 2010; 66 (17): 3248-3258.

30. Du H, Fuh RCA, Li J, Corkan LA, Lindsey JS. PhotochemCAD: A Computer-Aided Design and
Research Tool in Photochemistry. Photochem. Photobiol. 1998; 68: 141-142.

31. Rose J. Advanced Physico-chemical Experiments, first ed., Sir Isaac Pitman \& Sons Ltd., London, 1964, 257.

32. Kalkan A, Koca A, Bayır ZA. Unsymmetrical phthalocyanines with alkynyl substituents. Polyhedron. 2004; 23: 3155-3162.

33. Haas M, Liu SX, Kahnt A, Leiggener C, Guldi DM, Hauser A, Decurtins S. Photoinduced energy transfer processes within dyads of metallophthalocyanines compactly fused to a ruthenium(II) polypyridine chromophore. J Org Chem. 2007; 72: 7533-7543.

34. Kimura T, Kanota N, Matsui K, Tanaka I, Tsuboi T, Takaguchi Y, Yomogita A, Wakahara T, Kuwahara S, Nagatsugi F, Akasaka T. Preparation and electrochemical and optical properties of unsymmetrically substituted phthalocyanines with one or two trithiole rings and related symmetric derivatives. Inorg Chem. 2008; 47: 3577-3583.

35. Leznoff CC, Hall TW. The synthesis of a soluble, unsymmetrical phthalocyanine on a polymer support. Tetrahedron Lett. 1982; 23: 3023-3026.

36. Erdem SS, Nesterova IV, Soper SA, Hammer RP. Solid-phase synthesis of asymmetrically substituted "AB3-type" phthalocyanines. J Org Chem. 2008; 73: 5003-5007.

37. Kobayashi N, Kondo R, Nakajima S, Osa T. New route to unsymmetrical phthalocyanine analogs by the use of structurally distorted subphthalocyanines. J Am Chem Soc. 1990; 112: 9640-9641.

38. Kobayashi $\mathrm{N}$, Ishizaki $\mathrm{T}$, Ishii $\mathrm{K}$, Konami $\mathrm{H}$. Synthesis, spectroscopy, and molecular orbital calculations of subazaporphyrins, subphthalocyanines, subnaphthalocyanines, and compounds derived therefrom by ring expansion. J Am Chem Soc. 1999: 121; 9096-9110.

39. Kobayashi N, Nonomura T. First observation of the circular dichroism spectra of chiral subphthalocyanines with C3 symmetry. Tetrahedron Lett. 2002; 43: 4253-4255.

40. Meller A, Ossko A. Phthalocyaninartige BorKomplexe. Monatsh Chem. 1972; 103: 150-155.

41. Dabak S, Gül A, Bekaroğlu Ö. Hexakis(alkylthio)-substituted unsymmetrical phthalocyanines. Chem Ber. 1994; 127: 20092012.

42. Bhatt MV, Kulkarni SU. Cleavage of ethers. Synthesis. 1983; 249-282. 
43. Hirth A, Sobbi AK, Wöhrle D. Synthesis of a monofunctional phthalocyanine on silica. J. Porphyrins Phthalocyanines. 1997; 1: 275-279.

44. De la Torre G, Claessens CG, Torres T. Phthalocyanines: The need for selective synthetic approaches. Eur J Org Chem. 2000; 16: 28212830.

45. K. Sonagashira, in: F. Diederich, P.J. Stang (Eds.), Metal-catalyzed cross-coupling reactions. Wiley-V
CH, Weinheim, 1998, pp. 203-229.

46. Özçeşmeci M, Nar I, Hamuryudan E. Synthesis and electrochemical and spectroelectrochemical characterization of chloromanganese(III) phthalocyanines. Turk. J. Chem. 2014; 38: 1064-1072.

47. McKeown NB, Li H, Helliwell M, J. Porphyr. Phthalocyanines. A non-planar, hexadecasubstituted, metal-free phthalocyanine. 2005; 9(12): 841-845. 
